\title{
Shielding Idiosyncrasy from Isomorphic Pressures Towards Optimal Distinctiveness in European Filmmaking
}

Alvarez, José Luis; Mazza, Carmelo; Strandgaard Pedersen, Jesper; Svejenova, Silviya

Document Version

Final published version

Publication date:

2003

\section{License \\ CC BY-NC-ND}

Citation for published version (APA):

Alvarez, J. L., Mazza, C., Strandgaard Pedersen, J., \& Svejenova, S. (2003). Shielding Idiosyncrasy from Isomorphic Pressures: Towards Optimal Distinctiveness in European Filmmaking.

Link to publication in CBS Research Portal

\section{General rights}

Copyright and moral rights for the publications made accessible in the public portal are retained by the authors and/or other copyright owners and it is a condition of accessing publications that users recognise and abide by the legal requirements associated with these rights.

Take down policy

If you believe that this document breaches copyright please contact us (research.lib@cbs.dk) providing details, and we will remove access to the work immediately and investigate your claim. 
Papers in Organization, No. 49, 2003

No. 49

Shielding Idiosyncrasy from Isomorphic Pressures: Towards Optimal

Distinctivenes in European Film Making

José Luis Alvarez, Carmelo Mazza,

Jesper Strandgaard Pedersen

and Silviya Svejenova

Papers in Organization No. 49 ISSN 0906-0510

Copyright (C) 2003

New Social Science Monographs

Department of Organization and Industrial Sociology

Copenhagen Business School

Solbjerg Plads 3

DK-2000 Frederiksberg, Denmark

Phone: $\quad+4538152815$

Fax: $\quad+4538152828$ 


\section{Papers in Organizations - Editor's Foreword}

The purpose of the series Papers in Organizations is to work as a stepping-stone towards final publication in scientific journals. As such, $\mathrm{PiO}$ is a working-paper series, yet with a distinct position in the process towards final publication. The aim of $\mathrm{PiO}$ is to be the final steppingstone in that process:

- For the author $\mathrm{PiO}$ should add value to the work in progress through the editorial process. A publication in $\mathrm{PiO}$ is thus also a measure of the quality of the work - it is no longer simply a draft or an informal contribution to debates, but a work close to final publication.

- For the reader PiO should be a good place to be if one wants to keep track of contemporary research within the international field of organization studies. Indeed, many of the papers are manuscripts, which have been submitted to social science journals and as such appear in a rather final stage of completion. Others may contribute with empirical results from ongoing research projects or may in a more theoretical sense contribute to current academic disputes.

In this paper, the authors advance a contribution to new institutional theory proposing a micro theory that explains the existence of heterogeneity in a field despite isomorphic pressures towards homogenisation. The theory proposes that creative action can be understood ash deviant actors seeking to shield their idiosyncrasy from isomorphic pressures without getting excluded from the field it self. Drawing upon three empirical cases, the authors further argue that successful shielding and sustaining of creativity can be accomplished through different relational measures, notably and somewhat ironic, by forging their own 'iron cage' of tighter control of artistic freedom.

\section{Kjell Tryggestad/Søren Christensen}

Editors 


\title{
SHIELDING IDIOSYNCRASY FROM ISOMORPHIC PRESSURES: TOWARDS OPTIMAL DISTINCTIVENESS IN EUROPEAN FILM MAKING
}

\author{
José Luis Alvarez, Carmelo Mazza, \\ Jesper Strandgaard Pedersen and Silviya Svejenova
}

\begin{abstract}
This paper advances a micro theory of creative action by examining how distinctive artists shield their idiosyncratic styles from the isomorphic pressures of a field. It draws on the cases of three internationally recognized, distinctive European film directors - Pedro Almodóvar (Spain), Nanni Moretti (Italy) and Lars von Trier (Denmark). We argue that in a cinema field, artistic pressures for distinctiveness along with business pressures for profits drive filmmakers' quest for optimal distinctiveness. This quest seeks both exclusive, unique style and inclusive, audience-appealing artwork with legitimacy in the field. Our theory of creative action for optimal distinctiveness suggests that film directors increase their control by personally consolidating artistic and production roles, by forming close partnership with committed producer, and by establishing own production company. Ironically, to escape the iron cage of local cinema fields, film directors increasingly control the coupling of art and business, hence forging their own "iron cage".
\end{abstract} "[T]he unusual and paradoxical place that Pedro [Almodóvar] has been able to find: we are within the industry but we preserve our peculiarity." (Agustín Almodóvar, 2001).

Optimal distinctiveness: "social identity is viewed as reconciliation of opposing needs for assimilation and differentiation from others.” (Marilynn Brewer, 1991).

\section{Introduction}

New institutional theory has sought to explain why organizational actors show compliance and similarities (DiMaggio and Powell, 1991). It has argued that the establishment penalizes deviant actors making their access to resources and opportunities difficult (Becker, 1982; Baker and Faulkner, 1991; Zuckerman, 1999). Despite of penalties for deviance and illegitimacy discounts, however, distinctive actors persist and increase the heterogeneity of a field. This paper contributes to new institutional analysis by proposing a micro theory of creative action to shield singularity from isomorphic pressures. It 
draws on the cases of three internationally recognized European film directors - Pedro Almodovar (Spain), Nanni Moretti (Italy) and Lars von Trier (Denmark) - who have overcome restrictions of the status quo and penalties for not fitting into pre-established niches. Unlike classical accounts of maverick artists losing their exceptional status once the conventional field has accepted their work (Becker, 1982), the three directors sustain both idiosyncrasy and audience appeal by incessant experimentation and self-renewal, at times rebelling even against their self-imposed conventions.

This paper advances milestones of action theory for exclusivity and inclusion in creative domains. For the purpose, we bring in the social psychological notion "optimal distinctiveness" that views social identity as a reconciliation of opposing needs for assimilation and differentiation from others (Brewer, 1991). We suggest that optimal distinctiveness is especially relevant for creative industries where artists need both inclusion to get resources and differentiation to attain recognition for their talents. In the quest for optimal distinctiveness, we argue, film directors not only break away from the iron cage of a field's conventions. As our study revealed, they also tend to forge their own "iron cage" by controlling the coupling of art and business through own production hub, close partnership with committed producer, and/or personally consolidating creative and production roles.

The paper proceeds as follows. First, it reviews core concepts of isomorphism and maverickness to ground theoretically the need for creative action in shielding idiosyncrasy from isomorphic pressures. Second, it positions the idiosyncrasyisomor-phism duality in the context of a creative industry - i.e. cinema - that is particular for the need to appease art and business. Third, it outlines research design, data sources and methods for data analysis and provides brief introduction to the cases. Next, it compares the three cases to advance a micro theory of creative action. Finally, we make some concluding remarks on the importance of creative action in isomorphic fields.

\section{Isomorphism and Idiosyncrasy in a Field}

Film projects are complex temporary systems that pull together cultural, financial and material inputs (Faulkner and Anderson, 1987; DeFillippi and Arthur, 1998). Compliant, legitimate actors are more likely to get access to these resources. Hence, "[o]ne of the filmmaker's critical problems is to find ways to gain legitimacy" (Baker and Faulkner, 1991: 28). The legitimization of filmmakers, and hence their access to 
resources and opportunities, takes place in the cinema field.

Within the Institutional Theory of organizations the term field is defined as "those organizations that, in the aggregate, constitute a recognized area of institutional life: key suppliers, resource and product consumers, regulatory agencies, and other organizations that produce similar services and products" (DiMaggio and Powell, 1991: 143). To a large extent, this definition is "coterminous with the application of a distinctive complex of institutional rules" (Scott, 1995:135), which constitute 'coercive', 'normative' and 'mimetic' isomorphic pressures (DiMaggio and Powell, 1991). To get acceptance and inclusion, organisations tend to abide by those rules and conventions leading to standardisation of practices and isomorphism (Strandgaard Pedersen and Dobbin, 1997).

A cinema field experiences a range of isomorphic forces. Film making conventions, endorsed throughout formal schooling and/or with award giving, provide a normative ground for standardisation (Becker, 1982). Industry regulators and organisations in control of financial resources align producers' practices by tying subsidies for creative production up to certain artistic topics and budgetary routines, leaving the quality of artwork at the discretion of "expert" committees (Corsi, 2001).
Production companies, as gatekeepers that select creative innovations "in" or "out", have a say on the "blueprint" of what gets to the market (Hirsch, 1972). To reproduce suc-cess creative professionals then imitate the blueprint (Baker and Faulkner, 1991).

Macro-structural insights on isomorphism, however, are not necessarily sensitive to micro-explanations of institutional creation and change. Interests and agency are generative forces of change (DiMaggio, 1988; Lounsbury, 1997; Hirsch and Lounsbury, 1997; Alvarez, 2000). At least some institutions "result from successful attempts of extraordinarily creative, innovative, and productive individual actors who have the vision and genius not to accept or fine-tune existing ways of doing things but rather to consciously change the boundaries of what is possible" (Zucker and Darby, 1997: 503). Extraordinary individuals created the New York's Museum of Modern Art (DiMaggio, 1992). Content and technology entrepreneurs at the dawn of the Hollywood cinema initiated the field "de nouveau" and then contributed to its change (Jones, 2001). Hence, for fields to develop, actors have to balance needs for legitimacy by complying with norms with efforts for creation of unique identities (Lounsbury and Glynn, 2001). 
Extreme cases of uniqueness in a creative industry are mavericks who violate established conventions (Becker, 1982). Maverick film directors are articulate filmmakers with idiosyncratic approaches to filmmaking, away from ordinary practice. Becker's seminal work on art worlds defines maverickness in relational terms, i.e. how the person stands in relation to an organized art world (Becker, 1982: 228). Unlike work by integrated professionals whose collaborators have clear cues and expectations for action, maverick art is innovative and outside the limits of the existing art world's productions. Hence, upfront understandings are difficult and task co-ordination improves with long-term collaboration.

Creativity, both for mavericks and integrated professionals, is a social activity where the gifted person needs collaborative support to produce and diffuse works of art (Becker, 1982; Brass, 1995). It requires reconciliation of the expression of artistic values with the economics of mass entertainment (Lampel, Lant, and Shamsie, 2000). Academic inquiries have emphasised the critical role of a range of business activities and players (e.g., dealers, agents, production companies, distributors) as com-plementary to the artistic endeavour in producing and getting artwork to public (White and White, 1993;
Becker, 1982; Hirsch, 1972; Caves, 2000). However, they have also accounted for the inherent contradiction between creative work and humdrum commerce (Caves, 2000). The creative and the business subsystems have different interests and priorities. The former sub-system aims at expressing creative vision in a consistent way, "providing an inner standard to which reference is made" (Storr, 1985). The latter sub-system looks for delivering a box office film on time and within a budget (Baker and Faulkner, 1991: 286) and calls for legitimacy for subsequent access to finding project support.

Filmmaking as a creative undertaking needs integration (coupling) of business and artistic inputs embodied in entrepreneursadministrators from the management subsystem and professionals-artists from the technical sub-system (Hirsch, 1972; Baker and Faulkner, 1991). Coupling refers to the ways in which entities in a system relate to each other along the dimensions of distinctiveness and responsiveness (Orton and Weick, 1990). Due to their nature, art and business call for loose coupling solutions where artistic and business subsystems are distinctive yet responsive. Loose coupling as a pattern allows behavioural discretion and enhances experimentation and innovation (Orton and 
Weick, 1990), which are essential for creativity.

To provide milestones for a micro theory of creative action we undertook a multiple case study of renowned European film directors who are both idiosyncratic and profitable. Europe is dominated by the socalled auteur system originated in the late 1940s developments in Italy and further consolidated by the Nouvelle Vague in France and the journal Cahier du Cinema's circles. Unlike the producer-centered Hollywood cinema field where the producer "peoples" the projects (Baker and Faulkner, 1991), the European auteur system pronounces the director as the core (and most powerful) figure in filmmaking.

\section{Research Design}

The research design is a multiple-case study. The three cases - Pedro Almodóvar, Nanni Moretti and Lars von Trier - were approached with a preliminary theoretical framework derived from the extant literature (Yin, 1994; Brown and Eisenhardt, 1998). Theory building had affinities with grounded-theory approaches and came out of numerous iterations between the "deep cases" and the extant theory (Strauss and Corbin, 1998; Dyer and Wilkins, 1991).

\section{Data and Methods}

The study triangulated sources of evidence and methods for data collection (Yin, 1994). Data sources included interviews, company documents and visits (for the cases of Almodóvar and von Trier), press clippings and books on, and TV interviews and round table discussion with, the three directors, as well as their movies (see Table 1). Data gathering was based on established common guidelines along issues of interest related to the research question on how maverick filmmakers shield their idiosyncrasy from isomorphic pressures. Following the guidelines, the researchers conducted separately an in-depth, historical case study for each of the three filmmakers, with the case study on Almodóvar preceding that on Moretti and von Trier.

As is typical of inductive research, to advance theory out of "staggering volume of data" (Eisenhardt, 1989), the rich information gathered was integrated into detailed write-ups for each case. Then, within-case and across-cases' analyses were performed, following design indications for comparative qualitative research by Miles and Huberman (1984). Comparative displays were used for clarifying main points of convergence and divergence. In addition to initially specified issues of interest, we also allowed for new themes to emerge from the data. 
Table 1: Data Sources

\begin{tabular}{|c|c|c|}
\hline Pedro Almodóvar & Nanni Moretti & Lars von Trier \\
\hline $\begin{array}{l}9 \text { interviews: with his brother and } \\
\text { producer Agustín Almodóvar and } \\
\text { members of the production company }\end{array}$ & - & $\begin{array}{l}11 \text { interviews: with his long-term } \\
\text { business partner and producer } \\
\text { Aalbaek Jensen and other members } \\
\text { of the production company }\end{array}$ \\
\hline Company visits & - & Company visits \\
\hline Company press archive & Company press archive & Company press archive \\
\hline $\begin{array}{l}\text { Book with interviews with } \\
\text { Almodóvar (Strauss, 2001) }\end{array}$ & $\begin{array}{l}\text { Book with interviews with Moretti } \\
\text { (De Berardinis, 2001; Ranucci and } \\
\text { Ughi, 2001) }\end{array}$ & $\begin{array}{l}\text { Book with interviews with Von } \\
\text { Trier and other Danish directors } \\
\text { (Hjort and Bondebjerg, 2000) }\end{array}$ \\
\hline $\begin{array}{l}\text { TV programs, colloquiums, round } \\
\text { tables with Pedro Almodóvar's } \\
\text { participation }\end{array}$ & $\begin{array}{l}\text { TV programs, colloquiums, round } \\
\text { tables with Nanni Moretti's } \\
\text { participation }\end{array}$ & $\begin{array}{l}\text { TV program, interview with Lars } \\
\text { von Trier's partner Peter Aalbaek } \\
\text { Jensen }\end{array}$ \\
\hline $\begin{array}{l}\text { Local and international press } \\
\text { clippings, books on him }\end{array}$ & $\begin{array}{l}\text { Local and international press } \\
\text { clippings, books on him }\end{array}$ & $\begin{array}{l}\text { Local and international press } \\
\text { clippings, books on him }\end{array}$ \\
\hline
\end{tabular}

Each of us began by analysing individually cases and frameworks and then discussed these at several "interpretative meetings". Each time a new round of iterations was initiated between theory (to enlighten and to substantiate conceptually an empirically observed pattern) and data sources (to provide missing information for further induction). Secondary information, including books and articles from the business and film press on other film directors, artists, and gifted professionals alike, were used to refine our thinking and improve the soundness of our inferences. Theory building from cases was based on analytic generalisation, "in which previously developed theory is used as a template with which to compare the 
empirical results of the case study" (Yin, 1994: 38).

\section{The Cases}

In a recent article in Variety, Moretti, von Trier and Almodóvar are compared as three masters of the melodrama (Rooney, 2001). The article not only calls Moretti an "idiosyncratic auteur" but also labels him "a maverick" who is closer to Woody Allen than to "his Italian cronies". Furthermore, it refers to him as "the darling of Cahier du Cinema critics and regular on the French art-house network", something also said about Almodóvar. Almodóvar is also considered a maverick filmmaker (Dale, 1997) and an enfant terrible of the European cinema (Smith, 1999). A Washington Post's article calls von Trier the "maturing maverick of the Danish cinema", arguing that "[i]n a Scandinavian film tradition that has lacked vivid personalities since the heyday of Ingmar Bergman, von Trier is certainly larger than life" (Winters, 1996).

Both local and international cinema communities and professional organisations find the three directors creative and innovative. For more than twenty years they have been producing movies of their liking despite homogenising pressures of the cinema field. Such sustainable idiosyncrasy is rare and does not necessarily lead to success or acceptance in the field, or to a meaningful and coherent career path (White and White, 1993; Becker, 1982). In this sense, the three cases are critical instances (Yin, 1994) of maverick film directors who have managed to shield their idiosyncratic identities from isomorphic pressures. Table 2 provides details on their most prestigious European and Hollywood film awards and general information on their styles, projects and affiliations.

Almodóvar is an autodidact film director who claims "sole ownership" of his career. Critics have recognised that "with the clout to make any film he wants, he may yield more artistic freedom than any other European director" (Gritten, 1999). His line producer since the mid-1980s affirms that "[h] controls everything in his movies" (Fernandez, 2000). Almodóvar's films cut across genres, blending and redefining them (Thomas, 1991; Strauss, 2001). His creative style combines preparation and improvisation. A renowned Spanish cinematographer comments that "though sometimes the filming is very well prepared and the details have been worked out with almost manic precision, [Almodóvar] also improvises a lot and always incorporates new ideas" (Heredero 1994). Furthermore, unlike the majority of film directors who film without following the script sequence 
to economize on resources, Almodóvar

films sequentially, which gives him more control and additional freedom for changes

and improvisation.

Table 2: The Tree Film Directors: General information

\begin{tabular}{|c|c|c|c|}
\hline & $\begin{array}{c}\text { Pedro Almodóvar (1949-) } \\
\text { Spain }\end{array}$ & $\begin{array}{l}\text { Nanni Moretti (1953-) } \\
\text { Italy }\end{array}$ & $\begin{array}{c}\text { Lars von Trier (1956-) } \\
\text { Denmark }\end{array}$ \\
\hline 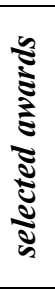 & $\begin{array}{ll}\text { - } & 1999 \text { Oscar Award, Best } \\
\text { - } & \text { Foreign Language Film } \\
\text { - } & 1999 \text { Cannes, Best Director } \\
& \text { FILM Honorary César, French } \\
\text { - } & 1999 \text { Goya Award, Spanish } \\
& \text { Film Academy, Best Director }\end{array}$ & $\begin{array}{ll}\text { - } & \text { 2001 Cannes, Palm D’Or, } \\
\text { Best Film } \\
\text { - } 1994 \text { Cannes, Best Director } \\
\text { - } 1986 \text { Berlin Golden Bear, } \\
\text { Best Film }\end{array}$ & $\begin{array}{ll}\text { - } & \text { 2000 Cannes Palm D’Or } \\
\text { - } & 1996 \text { Cannes, Grand Jury } \\
\text { Citation, Second Place } \\
\text { - } \quad \text { 1991 Cannes, Special Jury } \\
\text { Prize, Third Place } \\
\text { - } \\
\text { 1984 Cannes, Prize for } \\
\text { Technical Achievement }\end{array}$ \\
\hline 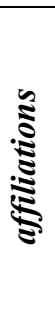 & $\begin{array}{l}\text { - politically sympathetic with } \\
\text { people with progressive } \\
\text { convictions } \\
\text { belongs to a social world of } \\
\text { fashion and interior designers, } \\
\text { artists, singers, etc. } \\
\text { - with Cahier du Cinéma }\end{array}$ & $\begin{array}{l}\text { - } \quad \text { politically sympathetic with } \\
\text { the former PCI } \\
\text { - } \text { party and currently with the } \\
\text { center-left coalition } \\
\text { "L'Ulivo" } \\
\text { - with Cahier du Cinéma }\end{array}$ & 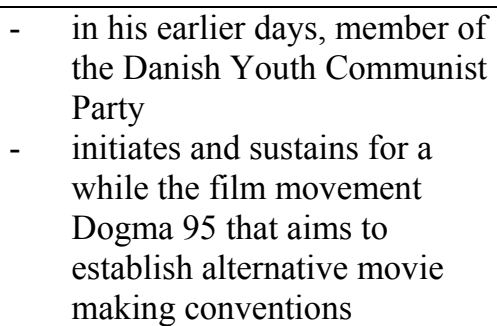 \\
\hline 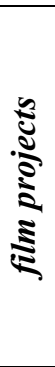 & $\begin{array}{ll}\text { Pace: } 13 \text { feature films (1980-2001) } \\
-\quad \text { mainly counts on own financing } \\
\text { and on a financial co-producer } \\
\text { - } \quad \text { persistent relationship with a } \\
\text { sales agent and with a } \\
\text { distribution company for the } \\
\text { USA - Sony Classic } \\
\text { (previously Orion) }\end{array}$ & 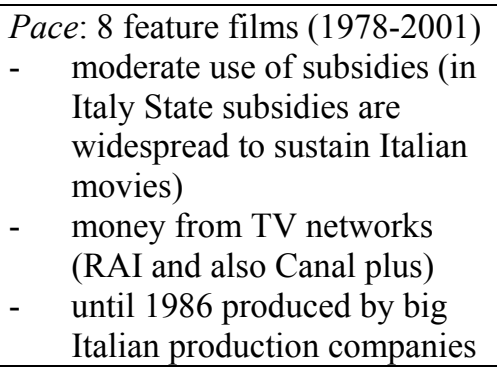 & $\begin{array}{l}\text { Pace: } 6 \text { feature films (1984- } \\
\text { 2001) } \\
\text { - } \quad \text { uses local (Danish), regional } \\
\text { (Scandinavian) and EU } \\
\text { subsidies to finance his } \\
\text { projects, in addition to own } \\
\text { resources }\end{array}$ \\
\hline 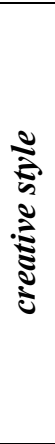 & $\begin{array}{ll}- & \text { Short movies in the } 1970 \mathrm{~s} \\
\text { - } & \text { First feature: } 1980 \\
\text { - } & \text { Narrow range of genres: mostly } \\
\text { - } & \text { comedy-drama } \\
\text { - } & \text { Chare deviance } \\
\text { - } & \text { Towarderistic topics and colors } \\
\text { - } & \text { Fissues in his last films in Spanish and in Spain }\end{array}$ & $\begin{array}{ll}- & \text { Short movies in the } 1970 \mathrm{~s} \\
\text { - } & \text { First feature: } 1978 \\
\text { - } & \text { Broad range of genres: } \\
\text { comedy, drama, } \\
\text { documentaries for TV } \\
\text { - } \quad \text { Genre-deviance } \\
\text { - } & \text { Characteristic topics and } \\
\text { characters } \\
\text { - } \quad \text { Towards higher universality } \\
\text { of issues in his last film } \\
\text { Films in Italian and in Italy }\end{array}$ & $\begin{array}{ll}- & 40 \text { commercials before } 1984 \\
\text { - } & \text { First feature: } 1984 \\
\text { - } & \text { Broad range of genre: dramas, } \\
\text { musicals, TV series } \\
\text { - } & \text { Genre-deviance } \\
- & \text { Obsession with the technical } \\
\text { - } & \text { Filmects of film } \\
& \text { in Scandinavia and abroad }\end{array}$ \\
\hline
\end{tabular}

Moretti is another self-made director who started his career by using very simple technology and small budgets, to become successful when still in his late twenties. He has never relied upon a single genre: he interweaves his characteristic autobio- 
graphical references in thrillers and documentaries, comedies and dramas. Though French film critics considered him an innovator within the "commedia all'italiana" genre, Moretti has constantly set himself apart from authors and directors in that genre tradition. He tends to present himself as an outsider, a film director opposed to everything "mainstream" in the Italian cinema. His inner drive, rather than some purposefully sought audience appeal, shapes his films:

...I do not think of the audience when making a movie. To me, directors and producers have done most damage when they have spoken for the audience. When reading of a press conference where the director and the producers claim, "We are not interested in intellectual arguments; we just want to make movies for the people", I am convinced it is a false statement. They are unable to make good movies and hence hide behind the argument "this is what people like". I do not know what people like (Ranucci and Ughi, 2001: 11).

Von Trier is the Scandinavian enfant terrible. Unlike Almodóvar and Moretti, he is formally trained in film directing. He is capable of continuously changing his style. As commented by his long-term partner and producer Aalbaek Jensen, "If there is a common element uniting von Trier's different faces,..., it is his genuine embracing of all points of view, his interest in expanding the boundaries of perception"
(Winters, 1996). Von Trier's maverickness is both in making alternative rules and in breaking those self-imposed rules. Initially fond of technical sophistication, in 1984 he received the Cannes Award for technical achievement. A decade later, with the Dogma 95 manifesto ${ }^{1}$, he returned to technical simplicity and purity as norms, only to disobey them again not before long. Von Trier affirms, "I always do something that I've never done before" (Kaufman, 2000). When asked whether he likes to disrupt the system, he replies: "If you like something, you want it to develop. I'm very fond of films, and I think all the films that I really like have pushed the medium a bit. It's as if you were in love with a woman or a man, or whatever, you want this person to develop...I would like to think I am doing this with film" (Kaufman, 2000).

In summary, the three directors consider themselves and are perceived as mavericks in their local cinema fields and also in the international movie arena. They have succeeded in making a steady string of

\footnotetext{
${ }^{1}$ The DOGMA 95 manifesto, developed by Lars von Trier and Thomas Vinterberg, and endorsed also with the help of Kristian Levring and Søren Kragh Jacobsen, is a 'Vow of Chastity' of ten rules that film directors have to obey to have their films certified as 'DOGMA' movies. A Dogma film rejects artifice, telling a contemporary story that is shot on location with a hand-handled camera, in natural light and with location sound. The manifesto pleads for refraining from personal taste and from being an artist, and forbids optical work or genre movies.
} 
feature films with both critical and public acclaim, demonstrating rare career resilience for an industry in flux and under strong standardization pressures. Below we discuss how they paved their way towards exclusivity and inclusion.

\section{Discussion}

Scholars have argued for the need of bridging old and new institutionalism, calling for a more complex theory of action that incorporates phenomenological approaches with those that focus on socially legitimated agency (Hirsch and Lounsbury, 1997). This paper is an attempt in bringing together the old institutional attention to agency with the new institutional argument in favor of institutions that shape action. Our analysis of the three cases in interplay with the theory revealed that optimal distinctiveness - at the boundary of agencydriven exclusivity and institutionally guaranteed inclusion - could inform on possible old-new institutional bridges. Below we provide some milestones of a micro theory of action that is also sensitive to isomorphic pressures, and hence could possibly be incorporated into and push forward new institutional theory.

Art and business as two complementary forces forge the iron cage of the cinema field. Art puts pressures for exclusivity and idiosyncratic style and movies. Business lends its support to film directors capable of attracting audience and of generating profits. Optimally distinctive film directors are those who reconcile the need for artistic differentiation and audience appeal. Mavericks, as an extreme case of differentiation, are usually unable to get audience appeal, or if they manage to achieve that, they tend to loose their unique status (Becker, 1982). Integrated professionals, as an extreme case of assimilation, tend to give up idiosyncrasy for inclusion and legitimacy in the field, and yield rather conventional artwork. Optimal distinctiveness (Brewer, 1991) provides a more balanced approach to action in an isomorphic field that reconciles the need for idiosyncrasy with the need to get resources from the field in order to keep producing artwork.

To shield idiosyncrasy while gaining inclusion, film directors have to couple successfully art and business. Our study reveals that getting away from the iron cage of isomorphism leads, ironically, to the forging of own iron cage. Artistic freedom calls for tighter control, with new levels of social structure emerging "from and only from efforts at control" (White, 1992: 234).

To increase control, film directors couple art and business in several domains (see Table 3). They personally consolidate 
artistic and production roles in filmmaking

(Baker and Faulkner, 1991; Menger, 1999)

becoming writer-director-producer hyphe-

nates. They also form long-term partner-

ships with trusted and committed producers and establish their own production companies. Finally, within their own artistic worlds, they nurture a cultural belief system based upon artistic freedom, integrity and experimentation.

Table 3: Domains of coupling of art and business

\begin{tabular}{|c|c|c|c|}
\hline & Pedro Almodóvar & Nanni Moretti & Lars Von Trier \\
\hline 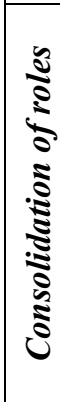 & $\begin{array}{ll}- & \text { Writer-director hyphenate } \\
- & \text { Involved in other style- } \\
& \text { related aspects of movies } \\
\text { - } & \text { Initial role-versatility. } \\
& \text { Later on focused on movie } \\
\text { making role-set }\end{array}$ & $\begin{array}{ll}\text { - } & \text { Writer-director-producer } \\
\text { multi-hyphenate } \\
\text { - } \quad \text { Versatile role-set } \\
\text { (production, distribution, } \\
\text { exhibition, own film } \\
\text { festivals, director of Venice } \\
\text { film festival) } \\
\text { - Cameo/his films (alter ego } \\
\text { Michele Apicella) } \\
\text { - Acts in friends' films }\end{array}$ & $\begin{array}{ll}\text { - } & \text { Writer-director hyphenate } \\
\text { - } & \text { Cinematographer and producer at } \\
& \text { times } \\
\text { - } & \text { Versatile role-set (TV directing } \\
& \text { and production, commercials, } \\
& \text { Dogma } 95 \text { movement) }\end{array}$ \\
\hline 离 & $\begin{array}{l}\text { Agustín Almodóvar } \\
\text { Partner in their company } \\
\text { Executive producer } \\
\text { Brother }\end{array}$ & $\begin{array}{l}\text { Angelo Barbagallo } \\
\text { Partner in their company } \\
\text { Co-producer of his movies } \\
\text { Friend }\end{array}$ & $\begin{array}{l}\text { Peter Albaek Jensen } \\
\text { Partner in their company } \\
\text { Executive producer } \\
\text { Friend }\end{array}$ \\
\hline 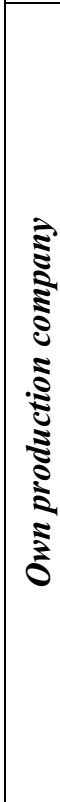 & $\begin{array}{l}\text { El Deseo (1985-) } \\
\text { Film development and } \\
\text { production } \\
\text { - } \quad \text { size: about } 10 \text { people } \\
\text { - } \quad \text { offices, and a film studio } \\
\text { in construction } \\
\text { - } \quad \text { "product mix" - mainly } \\
\quad \text { films of Almodóvar, } \\
\text { rarely complemented by } \\
\text { films of novel directors }\end{array}$ & 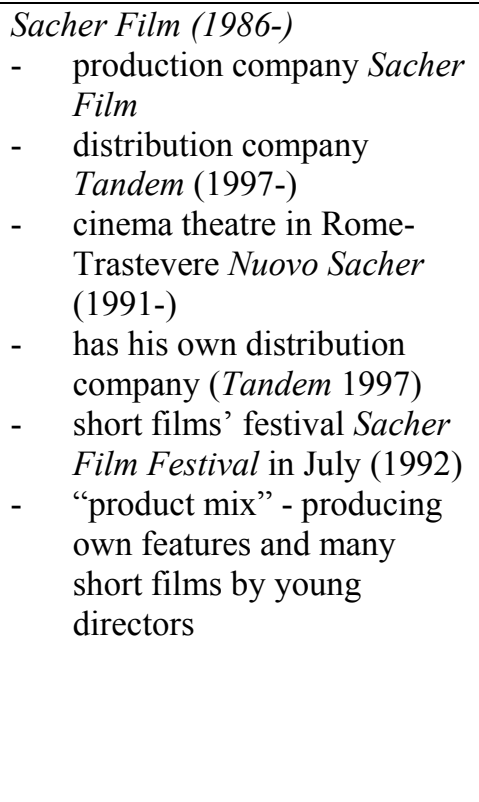 & 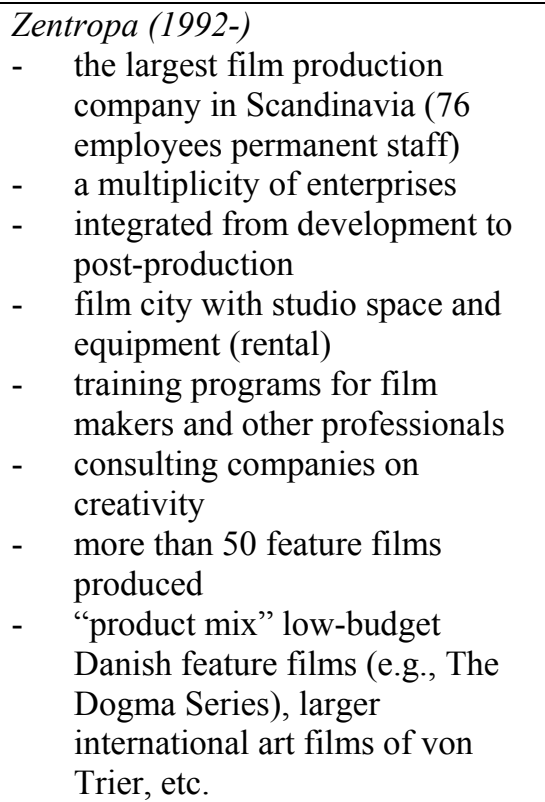 \\
\hline
\end{tabular}




\section{Consolidating Artistic and Business}

\section{Roles}

Film directors may consolidate the role of the writer and the producer in the set of roles they perform (Baker and Faulkner, 1991). Alternatively, they may decide to focus only on the creative side, leaving the production function to an alter ego, a very committed to their work partner, as we shall suggest below. This "resource perspective on roles" views roles as vehicles for actors looking for creative independence (Callero, 1994). The role is a resource in two ways: as a means to claim, bargain for, and gain membership of and acceptance by a social community, and to getting access to social, cultural, and material resources necessary for the pursuit of the artist's interests (Baker and Faulkner, 1991). The essential roles in a film project are director, writer, and producer (Morley and Silver, 1977). One way of using role as a resource to protect an idiosyncratic style in film is to combine these roles (e.g., a writer-director, a director-producer). Such role combinations could be elements of an imitation strategy by film professionals in the blockbuster era of Hollywood ${ }^{2}$ (Baker and Faulkner, 1991). Alternatively, as our study demonstrates, they could be

\footnotetext{
${ }^{2}$ Baker and Faulkner (1991: 288, in footnote) consider "The Godfather" (1972) the first blockbuster film and delineate a pre-blockbuster period (1962-1972) and a blockbuster period (19731980).
}

instrumental in shielding maverickness by increasing the film director's control over the process and the final output.

In addition to role consolidation, film directors could enlarge control and involvement through role-versatility (Menger, 1999). According to Menger, the creative person's working time and earnings are divided among the creative activity itself (film directing in our case), art-related work (e.g., management tasks in artistic organisations), and non-art work (any occupation, not related directly or indirectly with film making, mainly as a source of income). Below is an account of the role consolidation and the role versatility of the three mavericks and how it is conducive to endured artistic idiosyncrasy.

Almodóvar is an "artistic hyphenate" (a lingo to denote enactment of screenwriterdirector roles by a single professional) with involvement in a range of other creative aspects in his films - from set design and costumes to posters and press books. According to the Press Director of the Almodóvar brothers' production company El Deseo, "Pedro is definitely not a businessman. He does not perform any kind of business tasks, neither is he interested in such issues." He relies on his younger brother Agustín for the management of the 
company and the executive production of his films (such close director-producer partnerships are discussed further in the text).

Almodóvar used to be a versatile film director at the time he had neither reputation, nor resources to arrange financing of his movies. Thus, in the 1970s and early 1980s he performed a range of casual jobs followed by 12 years as a clerk for the Spanish telephone company, using the income to help accomplish his creative ideas. In this early stage, he was also involved in art-related activities, such as acting and singing in a spoof punk-rock band and writing for underground magazines. With the success of his movies, Almodóvar narrowed down his role versatility to focus on script writing and directing in search of professionalism and control in filmmaking.

\section{Moretti (unlike Almodóvar) consolidates} the production role in his role-set justifying it with the need to make high quality movies, as revealed in the quote below:

I wanted to be a producer...to react to the crisis situation of the Italian movie industry. The producer exists as an entrepreneur who wants above all to earn money. On the contrary, I am a producer who is first of all a director, that is to say a producer who likes nice movies. This is already counter-intuitive; I am producing neither to earn money, nor to make my movies earn money. Today in Italy - and I suppose in France too - the producer makes the deal before the movie is done. They get the money from money providers and at the same time, part of the money goes in their pockets: the deal is made! The more the film is apparently international, the more the money they get, so, paradoxically, producers are not interested in the quality, the success, the future of the film (De Berardinis, 2001).

In addition to being a "multi-hyphenate" for encompassing writer-director-produceractor in his movies, Moretti also maintains broad role versatility. Since 1988, he gives the Golden Sacher Awards to the best Italian movies, as a caricature to the traditional Italian movie awards and yet another manifestation of his own positioning as an outsider to the Italian cinema (De Berardinis, 2001). However, in 2001 he also accepted the role of a director of the prestigious mainstream and highly institutionalised Venice Film Festival, involvement at odds with his attempts at setting himself apart. On the non-art side of the role versatility set, he is currently involved in political manifestations and anti-corruption protests, overcoming his shyness and poor ability to speak in public. (A distancing attitude towards the mass media is attributed to Moretti, and as his alter ego in his movies - Michele Apicella states in the movie "Palombella Rossa", the reputation of a person is definitely damaged 
if his name appears on a newspaper page.) In his first movies, he openly pictured the rhetoric shallowness of some expressions that were common in the discourse of the political movements in the 1970s. The multi-hyp-henate and role-versatility reflect Moretti's dream of independence and control, made explicit with his first movie "Io sono un autarchico" ("I am autarchic").

Von Trier is a case between the mavericks Almodóvar and Moretti. Like them, he consolidates the roles of writer and director in his film projects. He also appears as actor (e.g. 'Element of Crime') and exercises production and cinematographer roles at times, the latter role reflecting his interest in pushing the technological frontiers of filmmaking. On the role versatility side, he directs and produces TV series and commercials. Defying the conventions of existing film worlds, with the Dogma 95 Manifesto he got involved in development and endorsement of an alternative standard. In an interview, von Trier emphasises the philosophy behind the Dogma 95 Manifesto and its rules:

“...[B]y limiting the freedom in
this way [by enforcing these
rules], we can acquire greater
freedom within the set limits."
(Hjort and Bondebjerg,
2000:229)

The big success of some Dogma-based productions (e.g. Palme D'Or to
'Celebration' by Vinterberg, Golden Bear to 'Last Song by Mifune' by KraghJacobsen and to 'Italian for Beginners' by Scherfig) reveals another paradox in creative fields. In some cases strict rules and limitations rather than complete freedom or huge budgets could trigger rather distinctive and acclaimed artistic creation (Hjort and Bondebjerg, 2000).

The three directors use role enactment to increase control over their film projects and to obtain degrees of freedom in their pursuit of exclusivity and inclusion. Exercising and getting credit for the role of writer, director and/or producer is a way to obtain inclusion in professional circles and to get the right to claim and manage certain resources. The coupling of two artistic roles (writerdirector) and the addition of a production role to them (in the extreme case) bind roles that unbind distinctiveness.

\section{Forming Tandem a with Committed Pro- ducer}

Another mechanism for shielding idiosyncrasy is to engage in on-going collaboration with a trusted partner (Alvarez and Svejenova, 2002a; 2002b). A stable, affect- and trust-based dyad of film director and producer reconciles classical principal-agent tensions between producers and film directors (e.g., Baker and Faulkner 1991; Fama 1980) allowing the pursuit of 
idiosyncrasy without opportunism or futile opposition. The trusted partner gets professional (exciting job occupation) and personal (contribution to the accomplishment of a talented artist) satisfaction.

The three directors work in intimate collaboration with a trusted partner that complements their role-set by specialising in or sharing activities more related to the business aspect of filmmaking. Almodóvar develops his trajectory in a symbiotic way with his brother, partner in their company, and executive producer of his movies Agustín Almodóvar (Alvarez and Svejenova, 2002a). Pedro Almodóvar wanted to start his production company "with somebody who was going to understand him intimately, from the essence, from the first idea of a film". Agustín took "a vital decision - to abandon my career... for love of Pedro... [and] to see the happiness and coherence of the career of a gifted person." Indispensable for his complete dedication, Agustín added, was his relationship with Pedro based on fidelity, affection, and fraternity, and ultimately his "love for Pedro." On a more instrumental level, Pedro needed Agustín's support to increase control over his artwork and to avoid the typical tension between art and business, exhibited in sterile opposition, mismatches of intentionality, or formal disagreement (Felipe, 1999).
The two sides of the relationship, as perceived by each sibling, is depicted in the following quotes:

"My relationship...with Pedro as
a director commenced in 1972
when I arrived in Madrid. I was
16 and coming from the deep
province...and I discovered a
different world... Pedro knew the
key people to access to the most
interesting ambiences. My bro-
ther was both my guard and
initiator. At that time... I was
accompanying him in every place
where he was showing them [his
shorts on Super 8 ], and I have the
impression that until now I keep
doing the same:...simply the
friends and the places have
changed, now they are much
more distinguished; our
appearance has also changed, we
wear tuxedos, but our motivation
and our relationship is un-
changed" (Agustín Almodóvar,
In Strauss, 2001: 63).

"Agustín has always been my first specta-tor. When an idea occurs to me, the first thing I do before I develop it is to tell him about it. He is always there.

Agustín... is the per-son who understands me best and who has always comprehen-ded in a very pro-found way every-thing I have done." (Pedro Almodóvar, In Strauss, 2001: 65).

Such strong affective relationship between the two siblings not only buffers Pedro Almodóvar from the field's isomorphic pressures. It also provides the committed support necessary for the forming and maintaining of his distinct art world. 
The main partnership between Nanni Moretti and Angelo Barbagallo is based on a long-term friendship, which has remained largely unacknowledged by the press. From a legal viewpoint, Barbagallo is the sole administrator of the company, while Moretti has the general right to operate on behalf of it. Barbagallo appears in "Caro diario" in the last episode of Moretti's tumor therapy. Asked about how he works on preparing a film and how important the collaboration with the same team is for him, Moretti responds:

\begin{abstract}
"Rather than a team, we are two people - Angelo Barbagallo and me. [I]t's a choice that, on the one hand, has enabled me to work with other directors, with whom I worked well, producing their features. On the other hand, having our own production company, and such a good partner, enabled me decide to make films unexpectedly, as happened with a film called "La Cosa", about the end of the Communist Party in Italy. I was able to make documentaries or shorts, whatever we felt like" (Wootten, 2001).
\end{abstract}

Distinguishing between conventional relationship with producer and relationship based on close partnership, such as the one he has with Barbagallo, Moretti explains:

\footnotetext{
“...[W]hen you have typical relationship with film producer, the film will have very clear and distinct stages - scriptwriting, pre-production, filming, postproduction, editing and all the rest. Whereas in some films I have made in recent years, these stages have become much more blurred." (Wootten, 2001).
}

As Moretti further acknowledges, this is only possible when one has own production company (own production hub as a milestone in the theory for action in creative domains is discussed further in the text).

Lars von Trier and his partner Peter Aalbaek Jensen got acquainted at the National Film School of Denmark in the mid 1980s, von Trier having just graduated as a director and Aalbaek Jensen near graduation as a producer (Hjort and Bondebjerg, 2000). They both have a past in the Danish Youth Communist Party and are proud of their rebellious attitudes and identities. Aalbaek Jensen described the timing of their teaming up in the following way: "We were a good team. Lars had
just 'flopped' with 'Epidemic'
and I had gone bankrupt with my
first company, which had
produced 'Perfect World""
(Wilhelmsen, 2000).

Von Trier and Aalbaek Jensen perform two different roles in the company. Lars von Trier is the artistic force behind the most significant movies and television shows of Zentropa, such as "The Kingdom"(1994 and 1997), "Breaking the Waves" (1996), "The Idiots" (1998) and "Dancer in the Dark" (2000). Aalbaek Jensen, unlike Agustín Almodóvar, is an equally popular and public figure in the Danish cinema, 
known for his outgoing style (usually pictured in Armani suit and with a huge Cohiba cigar) and provocative comments on the film industry's establishment. As producer and managing director, he provides organisational and financial support for the films. Von Trier stays away from the daily management of the company and from the board of directors, yet he benefits from Aalbaek Jensen's commitment (Brorsen and Strandgaard, 2002).

A stable director-producer partnership enhances the director's control over the artwork. Though ubiquitous in artistic domains, such pairings are not necessarily stable (e.g., the failed tandem of Woody Allen and Jean Doumanian, his friend and business partner for almost four decades) and require constant nurturing and mutual commitment.

\section{Establishing Own Production Company}

Independent producers operate as archetypal entrepreneurs, finding scripts, assembling commitments from teams of actors and production personnel, and convincing studios and investors to fund the projects (Robins, 1993). The establishment of own hub by principals with creative vision reveals such entrepreneurial impulses (DeFillippiand Arthur, 1999) and needs to buffer peculiar creative styles from restrictions to creativity by traditional production organisations (Alvarez and Svejenova, 2002a).

In the case of Almodóvar, it was his need for working with complete freedom that pushed him to undertake the production venture with his brother. For his first movie Almodóvar had to establish a co-operative with the support of a theatre director as his unusual style precluded support from conventional art worlds. Almodóvar registered his own hub in 1985, after five films produced by different production companies, which not only intervened in the business aspects of his movies but also in their creative conceptions (Strauss, 2001). As his brother and producer Agustín summarized, "[i]f from the very beginning Pedro had had a producer who had said 'we have to favor...creativity because it is a treasure, El Deseo would never have existed." Pedro Almodóvar commented that "El Deseo is an idea of the two of us [Pedro and Agustín] and, as a film maker, I enjoy the freedom I give myself as a producer" (Strauss, 2001).

The company is named after the first independently produced film of Almodóvar "La ley del deseo" (“The law of desire") and has a few cultural peculiarities. First, as Agustin Almodóvar revealed in an interview, the staffing strategy is under the 
motto of finding the right job for the persons with whom the two brothers like collaborating. Hence, first the siblings are assured in somebody's professionalism and develop a quality relation with him or her, and next, when the financial situation of the company allows it, they bring that person into the company team and find a job that matches his or her professional skills. In addition, the company operates with a "key man clause" when dealing with distributors, sales agents or financial co-producers. Such repeated personified exchange enhances the creative freedom to Pedro Almodóvar, providing better understanding of his idiosyncratic style and vision and tailormade service and support for his movies.

Moretti has owned production company since 1986. It is named Sacher Film after the Viennese chocolate cake eulogized in his movie "Bianca". It has produced 8 movies by or with Moretti, as well as various short movies by young film directors. Moretti is not a fast filmmaker. There is always a time lag between his movies. The same is true for his production efforts - Sacher Film is not producing many movies, less than one per year. This could, in part, be explained with the quality sought by Moretti in film production and his inner drive in initiating new projects. Like Almodóvar, famous for reconvening and cherishing a troupe of actors as his "second family" (Corliss, 1999), Moretti tends to work with the same people. The use of the same troupe (including relatives like his father and old friends, similarly to Almodóvar giving roles to his late mother and to his brother-producer) was also due to Moretti's obsession to avoid press anticipation of his movies' contents.

Moretti and Barbagallo have also founded a distribution company, Tandem, a joint venture of Sacher (Moretti and Barbagallo) and Mikado., well known in the Italian movie industry company. Moretti's strategy was to vertically integrate the business leads to increased control over financing, sales and distribution. His movies are events that always create high expectations in both public and critics. As a consequence Moretti has never had problems in finding the financial resources for making his movies (it has to be acknowledged his movies keep being low budget). Nowadays, because of their high visibility and reputation, the companies Sacher and Tandem are in the position of sbeing able to financing their films.

Lars von Trier and Peter Aalbaek Jensen founded their film company Zentropa in 1992. According to Aalbaek Jensen, the goal of Zentropa is to create an alternative to the established Danish film society (Darmer, 2000: 188). It produces mainly 
"artistic" films outside of the mainstream categories that no other production firm in the Danish film industry would undertake due to the financial risks. Zentropa's distinctiveness lies also in its organisation as an umbrella for a constellation of more than forty companies encompassing a range of activities of the cinema value chain (from sales and distribution companies to post-production and animation studios). For risk diversification, a separate company is added to the constellation each time a new project is triggered. Such approach to organising is more conducive to experimentation and innovation than integration within a single large company.

While distinctive in its approach to projects and organisation, Zentropa has managed to develop good relationships with organisations and institutions that provide financial resources to film projects. It relies on subsidies as well as on independent investors. Between 1992 to 1997, Zentropa received more than 13 million Euro in subsidies from the Danish Film Institut (DFI), and still continues to receiving support from it though, paradoxically, openly sets itself apart from DFI. Zentropa has also attracted direct subsidies or interest free loans from Scandinavian and EU media supporting programs. Other sources of financing are the production of commercials and TV series. Furthermore,
Zentropa has just made an agreement with the competitor Nordisk Film on distribution and partial financing of a number of films (Dabelsteen, 2001).

Zentropa Productions has a permanent staff of 76 some of which are interns. The internship system is a 3-year program where students start as receptionists and are then allowed to work, for example, in Peter Aalbaek Jensen's office, or in the many different departments, such as sales or postproduction. They are urged to leave Zentropa after the third year to try something different, but they are welcome to return.

While both staff and management at Zentropa argue they are an unorganized company, there is a clear project-based integration of the functional departments (e.g., finance, law, production, postproduction, sales and marketing). Usually, a person from each department has overall responsibility for a film project. Finance, sales and law can also work for external parties as well as have a more strategic, coordinating role for the Zentropa group. This means that Zentropa is not only able to produce and sell films. It could also offer services from idea to market to other film companies. 
Having own production company enables to bundle and manage artistic and business inputs from within, thus accentuating the director's idiosyncrasy. It is also an inclusion mechanism because production companies, formally registered entities, are recognised as legitimate players in the field entitled to get bank loans or subsidies, and to negotiate and sign binding contracts with other players in the field. Hence, production companies become a vehicle for both exclusivity and inclusion of the creative players.

\section{Forging Own Iron Cage to Shield Idio- syncrasy}

Our study revealed that shielding differentiation requires not only uncoupling from established systems. It calls for establishing own structures and conventions on how artwork is made and who gets included in one's art world. Role, relational and structural control mecha-nisms are needed to compensate for the decoupling and to maintain inclusion in the field despite of differentiation. They allow distinctive artists to get away from the iron cage of the field, simultaneously forging their own, tailored iron cage.

Below we discuss briefly three particular manifestations of the film directors' forging of own iron cage: Almodóvar's "families" and "key men", Moretti's festivals and Lars von Trier's Dogma 95 manifesto.

\section{Pedro Almodóvar: "Families" and "key men”}

Pedro Almodóvar has succeeded in building an audience-appealing coherent body of work with distinctive features colours, topics, and characters. According to Agustín, their own hub reveals "the unusual and paradoxical place that Pedro has been able to find: we are within the industry but we preserve our peculiarity" (Strauss, 2001: 66). He has consolidated an enduring niche position, which sets itself apart from the rest of the cinema field, yet it has been acknowledged legitimate.

Pedro works through "family" groups, his nuclei of trust and affection (Alvarez and Svejenova, 2002a). The collaboration of his biological family (most significantly his brother) is extended to accommodate his "second family" - the team of El Deseo (Francia, 2000: 33). He also nurtures his "family" of actors with nearly a dozen actors who have appeared in three or more films (Corliss, 1999). The Almodóvar brothers further forge the "iron cage" by choosing main partners through a "key-man clause." As Agustín explains it, whenever they have to deal with a particular company, be it for distribution or promotion, they do so through a specific 
person, whose departure from that company means the end of the contractual relation between El Deseo and that company. This is a very strong restriction that may lead to the loss of a client. However, it not only guarantees a differential service beyond what an ordinary firm would get. It also provides enforcement of the "Pedro's way". Through this enforcement it secures sustainability and perpetuation of his distinctiveness. A reason for Almodóvar's reluctance to film in Hollywood is precisely the need to abandon his own controlled and committed environment and to abide by alien norms and rules that would inevitably restrict his creative freedom.

Almodóvar does not deliberately aim at establishing a parallel standard to be followed by others. However, by attaining a peculiar creative style that becomes identifiable as a label, he becomes a role model, followed in a mimetic way by new generations of filmmakers. This mimetic isomorphism (DiMaggio and Powell, 1991) enlarges the influence of his creative style in the field.

\section{Nanni Moretti: Film festivals}

Moretti's approach to defining a niche and own standard resembles the normative influence exercised by a professional community on its members. Moretti's "normative" influence is revealed in the awards and the festival as myths and rituals of conformity (Meyer and Rowan, 1977). The film festivals he organises and runs can be seen as occasions of niche by selecting participants and awarding output with certain features. Moretti's short film festival is a very peculiar forum as its jury consists of only two people - Moretti and his producer and friend, Barbagallo.

The same originality regards the "Golden Sacher," awarded by the same jury under the same premises. As it is stated in the award's ironic rules, a "Golden Sacher" will not be given to directors whom Moretti dislikes. Young directors, sometimes after a fair commercial success, have won the "Golden Sacher". The awards given by Moretti and Barbagallo seem to be an attempt at setting a kind of "parallel cinema field", or a fully-fledged maverick niche within the establishment. It would be interesting to further trace how Nanni Moretti's chairing the 2001 Jury of the Venice Film Festival, the most important and mainstream festival in Italy, reconciles with his drive for endorsing an alternative standard to the Italian cinema establishment.

\section{Lars von Trier: Dogma 95 filmmaking conventions}

Of the three directors, von Trier is most explicitly attempting to consolidate own 
conventions through the Dogma 95 manifesto, which he developed together with his three 'Dogma-brothers' (See Note 1). Dogma 95 breaks with the film making conventions, advancing stringent rules against artifice in shooting, lighting, sound, plot, and prohibiting any aesthetic claim to the film director, who in addition must not be credited for his work (Hjort and Bondebjerg, 2000; Brorsen and Strandgaard, 2002). Twenty-five films from more than ten countries (USA, Denmark, Norway, Spain, France, Italy, Korea, Sweden, Belgium, Switzerland, etc.) have been certified and are credited in the official Dogma 95 website. Von Trier's attempt at setting standards with Dogma 95 could be seen as a rather coercive and normative effort to standardise part of the cinema field.

In all three cases, the directors form a shield - i.e. to forge an iron cage - for their idiosyncrasies. In the case of Almodóvar, it is a tightly knit art world of collaborators that perpetuate his style and artistic identity. In the case of Moretti, it is the attempt to "institutionalise" his vision of the cinema by award giving. Finally, von Trier becomes normative in the artistic space, explicitly defining rules by which other filmmakers must abide.

\section{Concluding Remarks}

In this paper we addressed a less studied yet increasingly important duality between idiosyncrasy and isomorphism. We showed how creative action is intended to rebel against isomorphic pressure by building uniqueness through strong ties and local practice. In examining these cases of film directors having achieved recognition for their creative individuality, we also outline how uniqueness, over time, may become a cage made of rules and standards that constrain creativity. In this sense, it can be argued that creativity could become trapped by its own success. To avoid the reemergence of self-produced isomorphic pressures, creative actors must be able to pursue their own renewal and to promote the further heterogeneity in the field itself.

Regarding the shielding and sustaining of optimal distinctiveness, we add to the literature on creative industries by sketching out three domains - roles, partnerships, and organisations - in which art and business are loosely coupled. We have examined how the pattern of coupling in each of these domains was conducive to protecting the director's distinctiveness from isomorphic pressures. In the domain of roles, we found in all three cases that control was regarded as important and that role combinations (i.e. the writer-director, and the director-producer hyphenates) and 
role versatility were means to safeguarding control over both art and business. In the partnership domain, a stable long-term relationship between film director and film producer was a source of committed support helped defeating any opportunism and mismatch of intentionality. The forming of tandems of director and producer is another mechanism for loose couplings of art and business that benefits from art-business complementarily and appeases their inherent contradictions. Finally, in the organisational domain film production companies owned by film directors are vehicles for binding art and business into a creativity-enhancing force. Combined these three domains appeared to be instrumental to the shielding of idiosyncratic identities from the isomorphic pressures of the field.

Related contribution is aimed at the advancing sociological accounts of maverickness. Our paper aimed at enriching Becker's (1982) original description of maverickness with the case of European maverick filmmakers. We argue that maverickness does not necessarily arise in professionals who have been trained in the field's conventions and found them restrictive (two of our distinctive cases were self-trained). It may also arise in cases of self-learned creative professionals who unaware of the field's conventions are capable of coming up with novel creative output that increases the field's heterogeneity. Furthermore, our cases question Becker's assertion that mavericks lose their uniqueness once accepted by the conventional field. Finally, artistic maverickness (idiosyncratic style) may have to be complemented with organisational maverickness (distinctive organisational solutions to serve the idiosyncratic style).

Additional line of contribution that was not initially intended, but emerged from the study, is related to the pushing forward of the frontiers of the cinema field. It addressed the issue of institutional entrepreneurship by casting light on how maverick film directors as active agents can bring change to their respective cinema fields by establishing parallel standards and defining niches.

Our micro theory of creative action was built on the assumption that to succeed in a creative domain, such as film making, film directors must look for optimal distinctiveness. Optimal distinctiveness bridges the artistic concerns for exclusivity with the business rationale for profitability that guarantees legitimacy, and hence inclusion in a field. The actions that directors undertake in building their optimal distinctiveness have to do with 
establishment and operation of mechanisms that bind art and business together. The directors free themselves from the iron cage of the field's isomorphism by enacting these mechanisms only to start forging their cages of personally imposed isomorphic pressures. Scholarly work in the New institutional tradition, we argue, would benefit from further attention to instances of optimal deviance and assessment of their functional and dysfunctional aspects as driving forces for a field's perpetuation and renewal.

\section{Acknowledgements}

We are grateful to Mary Ann Glynn and Kjell Tryggestad for their helpful commentaries for improving the paper. We also thank Candy Jones, Joe Lampel and the rest of the participants in the 2002 EGOS Colloquium's sub-theme on Creative Industries for their comments and ideas.

\section{References}

Alvarez, J.L. (2000) Theories of Managerial Action and Their Impact on the Conceptualisation of Executive Careers, in Peiperl, M. and M. Arthur (eds.), Conversations in Career Theory: Insights and Trends. Oxford, U.K.: Oxford University Press. (pp 127-137).

Alvarez, J.L. and S. Svejenova (2000) The Almodóvar Brothers' Film Factory: Unbinding Art through Tight Relationships. IESE Business School Teaching case DG$1331 \mathrm{E}$.

Alvarez, J.L. and S. Svejenova (2002a) Symbiotic Careers in Movie Making: Pedro and Agustín Almodóvar, in Peiperl, M., M. Arthur, R. Goffee, and N. Anand (eds.), Career Creativity: Explorations in the
Remaking of Work. Oxford, UK: Oxford University Press.

Alvarez, J.L. and S. Svejenova (2002b) Pairs at The Top: From Tandems to Coupled Careers. Harvard Business School Conference on Careers, London, June.

Baker, W.E. and R.R. Faulkner (1991) Role as Resource in the Hollywood Film Industry, American Journal of Sociology, 97(2): 279-309.

Becker, H. (1982) Art Worlds. Berkeley, CA: University of California Press.

Bourdieu, P. and L. Wacquant (1992) An Invitation to Reflexive Sociology. Cambridge, MA: Polity Press.

Brass, D.J. (1995) Creativity: It's All in Your Social Network, in C.M. Ford and D.A. Gioia (eds.) Creative Action in Organizations: Ivory Tower Visions and Real World Voices. Thousand Oaks, CA: Sage Publications. (pp 94-99).

Brewer, M.B. (1991) The Social Self: On Being the Same and Different at the Same Time, Personality and Social Psychology Bulletin, 17(5): 475-482.

Brooks, M. (1992) My Movies: The Collision of Art and Money, in Squire, J.E. (ed.) The Movie Business Book. New York, NY: Fireside. (pp 57-66).

Brorsen, J.P. and J. Strandgaard (2002) In the Borderland between Art and Business: Knowledge Management in Zentropa. Copenhagen Business School Teaching Case.

Brown, S. L. and K.M. Eisenhardt (1998) Competing on the Edge: Strategy as Structured Chaos. Boston, MA: Harvard Business School Press.

Callero, P.L. (1994) From Role-Playing to Role-Using: Understanding Role as a 
Resource, Social Psychology Quarterly, 57(3): 228-243.

Caves, R. (2000) Creative Industries: Contracts between Art and Commerce. Cambridge, MA: Harvard University Press.

Corliss, R. (1999) Loving Pedro, Time, Nov 29:59-60.

Corsi, B. (2001) Per Qualche Dollaro In Più. Milano: Baldini and Castoldi.

Dabelsteen, P. (2001) Zentropa Bliver Voksen. Copenhagen, Denmark: Politiken.

Dale, M (1997) The Movie Game. London, UK: Cassell.

Darmer, P. (2000) Zentropa I De Gyldne Palmers Skaer, in Steen Andersen, O. (ed.) Organisationer I Forandring. Copenhagen, Denmark: Copenhagen Business School Press. (pp. 185-209).

De Berardinis, F. (2001) Nanni Moretti. Milan: Il Castoro.

DeFillippi, R.J. and M.B. Arthur (1998) Paradox in Project-Based Enterprise: The Case of Filmmaking, California Management Review, 40(2): 125-139.

DeFillippi, R.J. and M.B. Arthur (1999) Paradox Revisited: A Reply to Phelan and Lewin, California Management Review, 40(2): 186-191.

DiMaggio, P. (1988) Interest and Agency in Institutional Theory, in Zucker, L.G. (ed.) Institutional Patterns and Organizations; Culture and Environment, Cambridge, MA: Ballinger. (pp. 3-21).

DiMaggio, P. (1992) Nadel's Paradox Revisited: Relational and Cultural Aspects of Organizational Structure, in Nohria, N. and R. Eccles (eds.), Networks and Organizations: Structure, Form, and
Action. Boston, MA: Harvard Business School Press.

DiMaggio, P.J. and Powell, W.W. (1991) The Iron Cage Revisited: Institutional Isomorphism and Collective Rationality in Organizational Fields, in Powell, W.W. and P.J. DiMaggio (eds.), The New Institutionalism in Organizational Analysis: Chicago, IL: The University of Chicago Press. (pp 63-82).

Dyer Jr., W.G., and A.L. Wilkins (1991) Better Stories, Not Better Constructs, to Generate Better Theory: A Rejoinder to Eisenhardt, Academy of Management Review, 16(3): 613-619.

Eisenhardt, K.M. (1989) Building Theories from Case Study Research, Academy of Management Review, 14(4): 532-550.

Fama, E.F. (1980) Agency Problems and the Theory of the Firm, Journal of Political Economy, 88: 288-307.

Faulkner, R.R. and A.B. Anderson (1987) Short-Term Projects and Emergent Careers: Evidence from Hollywood, American Journal of Sociology, 879-909.

Felipe, F. de (1999) Joel y Ethan Coen: El Cine Siamés. Barcelona, Spain: Glénat.

Fernández, J. (2000) Ciudadano Pedro, Retrato Amable De Familia, Dominical (El Periodico): 19 March.

Francia, J. J. (2000) Pedro Almodóvar, Magazine, da Vanguardia, 30th Jan: 26-33.

Gritten, D. (1999) One for the Girls. Interview With Pedro Almodóvar, The Telegraph Magazine, 14 August.

Heredero, C.F. (1994) El Lenguaje de la Luz: Entrevistas con Directores de Fotografía del Cine Español, Festival de Cine de Alcalá de Henares. 
Hirsch, P. (1972) Processing Fads and Fashions: An Organization-Set Analysis of Cultural Industry Systems, American Journal of Sociology, 77: 36-48.

Hirsch, P.M. and M. Lounsbury (1997) Ending the Family Quarrel: Toward a Reconciliation of "Old" and "New" Institutionalisms, American Behavioral Scientist, 40(4): 406-418.

Hjort, M. and I. Bondebjerg (2000) Instruktørens Blik. Copenhagen, Denmark: Rosinante Publisher.

Jaglom, H. (1992) The Independent Filmmaker, in Squire, J.E. (ed.) The Movie Business Book. New York, NY: Fireside. (pp 74-81).

Jones, B. (1998) The New Almodóvars. Capitals, September: 36-37.

Jones, C. (2001) Co-Evolution of Entrepreneurial Careers, Institutional Rules and Competitive Dynamics in American Film, Organization Studies, 6: 1895-1920.

Kaufman, A. (2000) Interview: Lars von Trier Comes Out of the Dark. www.indiewire.com

Lampel, J., T. Lant and J. Shamsie (2000) Balancing Act: Learning from Organizing Practices in Cultural Industries, Organization Science, 11(3): 263-269.

Lounsbury, M. and M.A. Glynn (2001) Cultural Entrepreneurship: Stories, Legitimacy and the Acquisition of Resources, Strategic Management Journal, 22: 545-564.

Lounsbury, M. (1997) Exploring the Institutional Tool Kit: The Rise of Recycling in the U.S. Solid Waste Field, American Behavioral Scientist, 40(4): 465477.
Mazza, C (2002) Nanni Moretti: Maverick to be independent. Case Write-up.

Menger, P.M. (1999) Artistic Labor Markets and Careers, Annual Review of Sociology, 25: 541-574.

Miles, M.B. and A.M. Huberman (1994) Qualitative Data Analysis. Thousand Oaks, CA: Sage Publications.

Miller, D. and J. Shamsie (1996) The Resource-Based View of the Firm in Two Environments: The Hollywood Film Studios from 1936 To 1965, The Academy of Management Journal, 39(3): 519-543.

Morley, E. and A. Silver (1977) A Film Director's Approach to Managing Creativity, Harvard Business Review, March-April: 59-70.

Orton, J.D. and K.E. Weick (1990) A Reconceptualization: Loosely Coupled Systems, Academy of Management Review, 15(2): 203-233.

Pfeffer, J. and G. Salancik (1978) The External Control of Organizations. New York, Harper and Row.

Phelan, S.E. and P. Lewin (1999) Paradox in Project-Based Enterprise: What Paradox?, California Management Review, 42(1): 180-186.

Ranucci, G. and S. Ughi (2001) Nanni Moretti. Roma: Dino Audino Editore.

Robins, J.A. (1993) Organization as Strategy: Restructuring Production in the Film Industry, Strategic Management Journal, 14: 103-118.

Rooney, D. (2001) Helmer savors "Room" For Growth, Variety, June 4-June 10. 
Scott, W.R. (1995) Institutions and Organizations. Thousand Oaks, CA: Sage Publishers.

Silver, A.J. (1975) The Management of Creative Process in a Temporary System. Doctoral dissertation. Graduate School of Business Administration. Harvard University.

Smith, P.J. (1999) Is This Man the Last Auteur in Europe?, The Independent on Sunday. 22 August.

Storr, A. (1985) The Dynamics of Creation. New York, NY: Atheneum.

Strandgaard Pedersen, J. and F. Dobbin (1997) The Social Invention of Collective Actors - On the Rise of the Organization, American Behavioral Scientist, 40(4) : 431443.

Strauss, A. and J. Corbin (1998) Basics of Qualitative Research: Techniques and Procedures for Developing Grounded Theory. Thousand Oaks, CA: Sage Publications.

Strauss, F. (2001) Conversaciones con Pedro Almodóvar. Madrid, Spain: Ediciones Akal.

Thomas, N. (1991) International Dictionary of Films and Filmmakers-2. Directors. Chicago, IL: St. James Press.

White, H.C. and C.A. White [1965](1993) Canvases and Careers: Institutional Change in the French Painting World. Chicago, IL: The University of Chicago Press.

White, H. (1992) Identity and Control. A Structural Theory of Social Action. Princeton, NJ: Princeton University Press.
Wilhelmsen, K. (2000) Iscenesætteren, Jyllandsposten. April 16.

Winters, L. (1996) Lars von Trier: Hot Danish Director, The Washington Post, November 24.

Wootten, A. (2001) Nanni Moretti, Regus London Film Festival interviews 2001: November 17.

Film.guardian.co.uk/rlff2001.

Yin, R.K. (1994) Case Study Research. Thousand Oaks, CA: Sage Publishers.

Zucker, L.G. and M.R. Darby (1997) Individual Action and the Demand for Institutions: Star Scientists and Institutional Transformation, American Behavioral Scientist, 40(4): 502-513.

Zuckerman, E. W. (1999) The Categorical Imperative: Securities Analysts and the Illegitimacy Discount, American Journal of Sociology, 104(5): 1398-1438. 
No. 1: Schultz, Majken (1991): Transitions Between Symbolic Domains in Organizations.

No. 2: Borum, Finn (1991): Innovating under Norms of Rationality.

No. 3: Pedersen, Jesper Strandgaard (1991): The Unisys Merger When Lovers Meet or a Wellarranged Marriage?

No. 4: Hatch, Mary Jo (1991): The Dynamics of Organizational Culture.

No. 5: Kristensen, Peer Hull (1991): When Labour Defines Business Recipes.

No. 6: Westenholz, Ann (1991): Paradoxical Thinking and Change in the Frames of Reference.

No. 7: Ehrlich, Sanford B. and Mary Jo Hatch (1991): Where there is Smoke: Spontaneous Humor as an Indicator of Paradox and Ambiguity in Organizations.

No. 8: $\quad$ Mikkelsen, Flemming (1991): Industrial Conflict in Scandinavia 1848-1990.

No. 9: Borum, Finn and John K. Christiansen (1993): Actors and Structure in IS Projects: What makes Implementation happen?

No. 10: Larsen, Henrik Holt (1993): Experiential Learning in Management Development - A Danish Case Study
No. 11: Kreiner, Kristian and Majken Schultz (1993): Soft Cultures Symbolism in International R\&D Projects

No. 12: Marginson, Paul (1993): The Multidivisional Structure and Corporate Control: Explaining the Degree of Corporate Coordination over Decisions on Labour Relations

No. 13: Hatch, Mary Jo and Majken Schultz (1993): Functionalism and Symbolism in Cultural Studies: From Theoretical Prisons to Methodological Interplay.

No. 14: Nielsen, J. C. Ry and Pål Repstad (1993): From Nearness to Distance - and Back: on analyzing your own organization.

No. 15: Mikkelsen, Flemming (1993): Strikes among Public Employees in Denmark

No. 16: Huard, Pierre Finn Borum (1993): Social Dynamics of a Novel Activity - The Case of Prenatal Diagnosis in France.

No. 17: Hatch, Mary Jo (1994): Reading Irony in the Humor of a Management Team: Organizational Contradictions in Context.

No. 18: Scheuer, Steen (1994): HRM Under Collective Bargaining: The Sociological Perspective. 
No. 19: Hegewisch, Ariane and Henrik Holt Larsen (1996): European Development in Public Sector Human Resource Management.

No. 20: Dobbin, Frank and John R.

Sutton (1996): The Rights

Revolution and Organizational Differentiation.

No. 21: Pedersen, Jesper Strandgaard and Frank Dobbin (1997):

Constructing Organizations:

Neoinstitutionalism and

Organizational Culture.

No. 22: Larsen, Henrik Holt (1997): In Search of Management Development in Europe - from self-fulfilling prophecies to organizational competence.

No. 23: Borum, Finn (1997):

Transforming Hospital

Management: The (Im)possibility of Change.

No. 24: Hegland, Tore Jacob (1997): From a Thousand Flowers to Targeted Development.

No. 25: Norus, Jesper (1998): The Constitution of the Biotechnological Industry - the co-evolution of networks and strategies.

No.26: Karnøe, Peter \& Raghu Garud (1998): Path Creation and Path Dependence in the Danish Wind Turbine Field.

No. 27: Christensen, Søren (1998): Hvad er "værdier" værd i institutionel organisationsanalyse?

No. 28: Steyaert, Chris (1998): 'Human, all too human management': Constructing 'the subject' in HRM. 
No. 29: Scheuer, Steen (1998): Union Presence and Hours Worked.

No. 30: Kjær, Peter (1998): Fra bedriftscele til aktør-i-marked. Den driftsøkonomiske konstruktion af virksomheden $1915-1945$

No.31: Augier, Mie \& Kristian Kreiner (1999): The Intelligence of Action: An Interview with James G.March

No. 32: Augier, Mie \& Kristian Kreiner (1999): Bringing Reality Back to Economics: An Interview with Herbert A. Simon

No. 33: Augier, Mie \& Kristian Kreiner (1999): Behavioral Economics and the Firm: An Interview with Richard M. Cyert

No. 34: Augier, Mie \& Kristian Kreiner (1999): Rationality, Institutions, and Economis Processes: An Interview with Richard N. Langlois

No. 35: Nygaard, Claus (1999): Strategic Actions of Embedded Small and Medium Sized Enterprises

No. 36: Flüssel, Lanni \& Susse Georg (1999): Institutionalization of Environmental Concerns Making the Environment Perform

No. 37: Sumita Raghuram, Manuel London \& Henrik Holt Larsen (2001): Flexible Employment Practices in Europe - Country versus Culture

No. 38: Sumita Raghuram \& Henrik Holt Larsen (2001): Human Resource Practices for Telework: The European Experience
No. 39: David Metz \& Ann Westenholz (2001): Identity Creation in Temporary and Scattered Work Communities in a Relational Perspective

No. 40: Kjell Tryggestad (2001): Reversible Statistics: The Making of Statistical Facts and Artifacts in Economics

No. 41: Sumita Raghuram, Manuel London \& Henrik Holt Larsen (2001): Links Between Organizational Characteristics and Change in and Flexible Employment Practices in European Organizations

No. 42: Sami Bloutaiba \& Jesper Standgaard Pedersen (2002): Creating MBA Identity Between Field and Organization

No. 43: Per Vejrup-Hansen \& Flemming Agersnap (2002): Studieforløb og karriere. Sammenhæng mellem studielængde, andre studieforhold og lønudvikling blandt erhvervsøkonomiske kandidater

No. 44: Kjell Tryggestad (2002): ReDrawing the Boundaries of Explanation: An Emerging Third Way

No. 45: J.C. Ry Nielsen \& Morten Ry (2002): The Danish Public Sector - An Endless Journey of Organisational Change

No. 46: Niels Christian Mossfeldt Nickelsen (2002): Moulding Singularity - Examining Multiplicity in Designing

No. 47: Raghu Garud \& Peter Karnøe (2002): Embedded and 
Distributed Agency in

Technological Entrepreneurship

No. 48: Torben Elgaard Jensen (2003):

Aktør-Netværksteori - en

sociologi om kendsgerninger, karakker og kammuslinger

No. 49: José Alvarez, Carmelo Mazza, Jesper Strandgaard and Silviya Svejenova (2003): Shielding Idiosyncrasy from Isomorphic Pressures: Towards Optimal Distinctivenes in European Film Making

No. 50: Henriette Langstrup Nielsen (2003): Self-Monitoring: IT and the Construction of the Competent Patient 